\title{
Unraveling Disability Participation in Indigenous Peoples
}

\author{
Isnenningtyas Yulianti \\ Komnas HAM \\ Email: tyas.yulianti@gmail.com \\ Nurrahman Aji Utomo \\ Komnas HAM, \\ Email: nurrahmanajiutomo@gmail.com
}

\begin{abstract}
The issue of person with disability in indigenous peoples is closely related to issues pertaining to enjoyment of social development as well as inclusive citizenship. Indigenous peoples face potential discrimination and exclusion from every social development from every aspect of life. This condition becomes more vulnerable if it occurs in persons with disabilities. The issue of disability discrimination in indigenous peoples, still often neglected in the environment of its own community, as well as in larger systems of society and state. The areas of Toraja, and Bali, were focused on for this research and taken for their larger representation. Facts and analyses collected through this research demonstrate that indigenous persons with disabilities face various layers of discrimination and violations of gender and disability status. The characteristics of indigenous peoples determine the treatment of persons with disabilities within specific communities. Most noticeable is the lack of friendly service for persons with disabilities in their own societies. Therefore, people with disabilities in indigenous communities deserve greater and more accessible opportunities to participate in customary institutions and emancipation beyond the scope of protection and the fulfilment of rights by the government.
\end{abstract}

Keywords: Disability, Indigenous Peoples, Inclusive Participation

\section{INTRODUCTION}

The subject of persons with disabilities (PwDs) is placed into broad context for this research by the CRPD (Convention on the Rights of Persons with Disabilities) and in Law No. 8 of 2016 on Persons with Disabilities (UU PD). Based on The World Report on Disability quoted by the World Bank, in 2011 Mirna and Paul Sena confirmed that $15 \%$ of the world's population is comprised of persons with disabilities. If applied to indigenous peoples, which number around 360 million people worldwide, that ratio would mean that there are 54 million people with disabilities in indigenous communities throughout the world. 
Indigenous peoples with disability conditions may experience multiple forms of discrimination. The first layer is as indigenous people, who are sometimes viewed as second-tier people, and the second is as persons with disabilities. An additional layer of discrimination is applied if these conditions occur in individuals who are female or are children within indigenous communities. In the opening of the CRPD, it is asserted that women and girls with disabilities are at greater risk of violence, harassment, neglect, and exploitation.

Meanwhile, indigenous peoples are also concerned with issues deriving from the widespread impacts of development. The vulnerability of indigenous peoples is contributed to by the potential discrimination and exclusion faced during the development process. These threats can be observed in every aspect of life. One such threat is potential eviction from traditional territories as a result of development. This vulnerable condition is more poignant in persons with disabilities. The issue of social participation persons with disability in indigenous peoples, still often neglected in its environment and its own group, and even in the system of society and state. Disability within indigenous peoples themselves faces various layers of discrimination and from its disability status.

Both indigenous peoples and those with disabilities do not enjoy equitable access to education, health, employment, social security, mobility assistance, or services related to social rehabilitation. This inequitability is affirmed in the ill health suffered by indigenous peoples (and disabilities), resulting in reduced quality of life and more rapid deaths than ordinary people. Many Indigenous Peoples cannot access resident cards, family cards and other certificates which result in the community not being recorded in accessing social security and health insurance. The issue of distance to health services also makes indigenous peoples limited access to health services. The underlying cause for the disparity rests on health access for indigenous peoples. This is a challenge, since the right to health in the context of indigenous peoples' disability is still characterized by discrimination and marginalization. The groundwork for disentangling and managing the problems that Persons with Disability PwDs face in indigenous communities requires approaches and stages that clearly understand the character and needs of the vulnerable communities. To explain the context, this study illustrates the conditions in two areas, among others: Bali and Toraja. Each region was selected with a particular consideration between indigenous peoples and persons with disabilities. Kolok Village in Bali is a customary village with a majority population of PwDs, namely those that are mute and deaf. In addition, the many indigenous villages in Bali are still living with their customs. Toraja, in particular, is an area with strong roots and strong values.

Studies and research on the rights and participation of persons with disabilities have focused mainly on the rights of people with disability in general. Only a few have investigated the position and issue of indigenous peoples in Indonesia. A study conducted by Jane Kartika Propiona et al. ${ }^{1}$ asserted that persons with disabilities are

1 Jane Kartika Propiona et al, Buku Implementasi Hak Asasi Manusia di Indonesia: Hak Kesehatan dan Jaminan Sosial Bagi Penyandang Disabilitas di Kabupaten Daerah Tertinggal, (Pusat Penelitian Kemasyarakatan dan Kebudayaan: LIPI, 2013) 
citizens who can exist in every place, including disadvantaged areas. This assertion establishes their existence as a matter of local government, requiring that homework is prioritized to their benefit. Like other citizens, persons with disabilities have rights and deserve equal opportunities to meet basic needs and improve quality of life. This matter becomes more severe in the underdeveloped areas where the fulfilment of these rights is impacted by limitations in infrastructure. Meanwhile, related research has been done by Todhi and Aminatun. This research investigated women's disabilities in indigenous peoples and revealed new data about the reality of living as a woman or child with disabilities in an indigenous community.

The review discusses how customary institutions apply to persons with disabilities. From the study the researchers will take some examples of cases and models prevailing customary institutions. Concentrating on the participation of Indigenous Peoples, not many are found. The author discovers some related literature including the thesis of Argo Twikromo, "The Local Elite and The Appropriation of Modernity, the Case in East Sumba, Indonesia." The thesis examines the role of local people, especially the main actors who play the local elite. years have been envisaged that the modern state, especially the post-colonial state, is strong enough to abolish the cultural and political autonomy of the small community or often called the "traditional" society within their national boundaries.

Studies on Indigenous Peoples Participation tend to focus on participation in development. The article of Participation of Indigenous Peoples in the implementation of regional autonomy in Kalimantan. The paper discusses the participation of indigenous peoples in development programs, especially those related to regional autonomy. The pattern of participation is demonstrated by the community in its participation in overseeing, providing donations and securing local assets. Focused concentrations on the participation of persons with disabilities within indigenous communities are still minimal.

This paper will explore the participation of indigenous persons with disabilities in their own communities. The leading research question for this project was as follows what is the scope of participation for PwDs in indigenous communities, and the opportunities for participation as related to inclusion? This study explores the forms of disability participation in indigenous peoples, especially in Toraja and Balinese customs. This paper takes data with research on the protection and fulfilment of the rights of vulnerable groups in indigenous peoples in Toraja and Bali, conducted by Komnas HAM 2017.

\section{FINDING VULNERABILITY IN DOUBLE DISCRIMINATION}

This study seeks to set the context for discussions about disability in indigenous peoples, particularly when addressing the confrontations posed by development to questions of participation and empowerment in rights fulfilment for these persons. Such participation takes place within their realm as human beings and citizens, who are within the scope of the state's obligation to fulfil it. 
In the United Nations permanent forum on indigenous issues discussed about some terminology regarding indigenous peoples. Considering the many terminology of indigenous peoples, and there has not been an official word adopted by the United

Nations, there are a number of things to consider. This is then stated in Factsheet United Nation Permanent Forum on Indigenous Issues, "Who are indigenous peoples: ${ }^{2}$

1. Self-identification as an indigenous person who are acceptance as a member of the community by the community;

2. Historical continuity with pre-colonial and / or pre-settlement societies;

3. Strong relationship to the surrounding area and the natural resources of that area;

4. Different social, economic and political systems;

5. Different languages, cultures, and beliefs;

6. Forming a non-dominant group of people;

7. The preservation and preservation of the environment and their ancestral systems as distinctive societies.

Such identification efforts are possible because several human rights documents have explored the the complexity and fundamental criteria of selfidentification. ${ }^{3}$ In addition to identification, efforts to recognize indigenous peoples in Indonesia are still on going within the political sphere of law in the regions/local law (Perda).

1. The process can be observed after the Constitutional Court Decision No. 35 / PUU-X / 2012, because of which there were 69 local law products published between 2013 until 2016;

2. The existence of indigenous peoples;

3. Indigenous and customary forest areas;

4. Traditional village;

5. Implementing Agency of the legal products can be grouped in several ways, among others:

Proceeding from the arrangement of indigenous peoples in local legal products, the basis of recognition of indigenous peoples in Article 18B (2) of the 1945 Constitution, simply limits the extent of enforcement. Phrased in a different way, these limits ensure that indigenous and customary law is alive and does not conflict with legislation. At this stage, the recognition of indigenous peoples in local legal products became a definitive requirement of recognition. Conditional recognition that has been applied by the government (as long as it is still valid and

2 Factsheet United Nation Permanent Forum on Indigenous Issues, "Who are indigenous peoples?”. Archived on www.un.org/esa/socdev/unpfii/documents/5session_factsheet1.pdf.

3 Ibid, at para 4.

4 Yance Arozona et al., Pengakuan Hukum terhadap Masyarakat Adat: Tren Produk Hukum Daerah dan Nasional Pasca Putusan MK 35/PUU-X/2012, 2017, (Jakarta: Epistema Institute, 2017), at 3 .

5 Ibid, at 5 . 
not contrary to the laws and regulations $)^{6}$ has the potential to harm the community. Griffith holds that it is a case of weak legal pluralism for customary law to submit to state law because this case requires the recognition of the state for the customary law to be enacted. The weak legal pluralism consciously results in the conflation of customary law with the character of state law. Given the scope of positions that require recognition, including existence and protection, indigenous peoples are in a vulnerable position.

Another development in the recognition and protection of indigenous peoples regards the establishment of adat villages. Specifically, the establishment of adat villages using Local / Municipal Regulations that grant village's authority to self-rule based on their customary origins and rights. ${ }^{8}$ The implementation of such authority is concerned with the principle of diversity, ${ }^{9}$ to avoid discrimination within internal groups of the community. Such arrangements indicate the potential for discrimination within indigenous peoples.

Paradoxes within the scope of aforementioned vulnerable groups can be observed in sub-groups within indigenous communities. Article 5 of Law No. 39 of 1999 on Human Rights states that vulnerable groups include the elderly, children, the poor, pregnant women, and persons with disabilities. Vulnerable groups in other contexts require structural discrimination (social and environmental discrimination) and face difficulties in self-defence and therefore need special protection..$^{10}$ These groups include: women and girls, children, refugees, internally displaced persons, stateless persons, national minorities, indigenous peoples, migrant workers, disabled persons, elderly persons, HIV positive person and AIDS victims, Roma/Gypsies /Sinti." In practice, the elderly, children, the poor, pregnant women, and those with disabilities face inadequate protection against discrimination, thus exposing them to increased risk of discriminatory threats.

The scope of vulnerable groups demonstrates that indigenous peoples face a variety of discriminatory threats. Such discrimination may be born within the scope of self-regulating authority (customary institutions) and the role of government (or lack thereof) in protection of vulnerable groups. In Indonesia, vulnerability is measured as a person or group that causes base on experiences social problems. ${ }^{12}$ Vulnerability is a condition of instability as a result of social, economic, political, and catastrophic crises which can lead to social problems. In the PMKS Act

6 Faridda Patittinggi, "Peranan Hukum Adat Dalam Pembinaan Hukum Nasional Dalam Era Globalisası”, Majalah Ilmu Hukum Amanna Gappa, Vol.11 No. 13, Januari-Maret 2003, Fakultas Hukum Universitas Hasanudin Makassar, at. 411.

7 Pasal 103, Undang-Undang No. 6 Tahun 2014 tentang Desa, Arranging the authority of indigenous villages by rights of origin.

8 John Griffith, “What is Legal Pluralism' Journal of Legal Pluralis, 1986, nr-44, at 1-55.

9 Read Elucidation of Article 104 of Law 6/2014 on Village.

10 Sepuldeva, M., Van Banning, T., \& van Genugten, W. J. M. Human Rights Reference Handbook. (Costa Rica: University for Peace, 2004) at 317.

11 Ibid, Sepuldeva et al, at 317.

12 Https:/www.kemsos.go.id/content/kerentanan, Compare with Sepulveda. Sepuldeva, M., Van Banning, T., \& van Genugten, W. J. M. (2004). Human Rights Reference Handbook. Costa Rica: University for Peace at 317. 
(People with Social Welfare Problems) indigenous peoples are defined as groups that bear social welfare injustices or experience social casualties. Indigenous groups in PMKS are referred to as "Remote Indigenous Communities". ${ }^{13}$ Remote Indigenous Communities are groups of people or communities that live in relatively small groups in remote areas, who are deeply bound to their natural environment for resources to sustain their sociality and culture. They typically live isolation and can be viewed as 'backwardness' when compared to Indonesian society in general. To get rid of this picture, the Ministry of Social Affairs gives a more positive term, namely Remote Indigenous Communities (KAT). That was stated in Presidential Decree No. 111/1999 concerning the Development of Social Welfare of Remote Indigenous Communities, Kepmensos No. 06/PEGHUK/2002 concerning guidance on KAT Empowerment, and several Decree of the Director General of Social Empowerment of the Ministry of Social Affairs. The definition of the transfer community according to these rules is "social (cultural) groups relating to local and scattered and less involved in social, economic and political networks and services. ${ }^{14}$

These factors call for empowerment in the face of environmental change in a broad sense. ${ }^{15}$ From this paradigm stressed that indigenous peoples are one of the social issues that must get coaching, empowerment and attention. The effort of indigenous peoples to develop their communities is certainly the task of various elements of the nation, because indigenous people represent the part of this nation. Some important efforts that must be carried out by the government in the activities of empowering indigenous peoples are first, the reorientation of indigenous peoples in development, secondly, the social movement of indigenous peoples, the third stage, building the relations of indigenous peoples, the third stage, capacity building of indigenous peoples.

Although it has been categorized into 3 parts, but the approach to handling issues of Remote Indigenous Communities is identical to that of the Ministry of Social Affairs Regulation No. 12 Year 2015 on Social Empowerment of Remote Indigenous Communities. ${ }^{16}$ The treatment of these three categories is the same. In addition, many programs are considered incompatible with the social wisdom of local indigenous people who have lived according to their principles and beliefs for for hundreds of years.

13 Regulation of The Minister of Social Republic of Indonesia Number 08 of 2012 Concerning Data Guidelines and Management of Data Consists With Problems of Social Welfare and Potential and Sources of Social Welfare has stated about types, definitions and criteria with the problem of social welfare (PMKS) and potential and sources of social welfare (PSKS).

14 Puji Hadiyanti, Pemberdayaan Masyarakat Adat Terpencil melalui Model Pendidikan Luar Sekolah, Jurnal Ilmiah VISI PTK-PNF - Vol. 4, No.2, Desember 2009, at 197.

15 See Nawari Ismail, Perubahan Sosial Budaya Agama Dam, (Deepublish: 2016), at 33.

16 The empowerment referred to in the regulation is the Social Empowerment of KAT is a series of policies, strategies, programs and activities directed to empowering and trusting the local KAT to find the problems and needs and their resolution efforts based on their own strengths and capabilities through protection, strengthening, development, consultation and advocacy for the improvement of social welfare level (CHAPTER I, General Provisions of Article 1, paragraph 3). 
The government must understand that indigenous peoples are a society that need to be empowered with the same standard needs of the country and that it has a duty to keep indigenous peoples connected to their cultural roots. The community housing program provided by the government for indigenous communities is extremely so far removed from local cultures and customs, and tradition, with the idea of "residence". The current methods of government assistance are also unsuccessful because the aid model has changed the way of life and customs of indigenous peoples. After this aid ceases, indigenous peoples will return to their original customs or customs. ${ }^{17}$

Persons with disabilities in indigenous peoples, also experience a double vulnerability. First, as indigenous peoples, they are excluded as indigenous peoples in general, then as disabilities they are excluded in their customary environment the beliefs that disabilities are residuals or curses is not necessarily a barrier to the active involvement of persons with disabilities in everyday life. Rather, this condition should also be adjusted to every existing customary institution. Referring to this vulnerability, inclusive conditions are needed in social lives.

Inclusiveness is often confronted with issues of citizenship. One way to think about inclusive citizenship, within the boundaries of a nation state, is to emphasize that the main components of citizenship apply to all citizens alike. These are: membership and belonging; rights and obligations that flow from the membership; and equality of status.. ${ }^{18}$ In this context, developing "inclusive citizenship" is a situation in which all can act as citizens and to maintain transparency and open communication with the state so as to of reduce the fragility of the state. ${ }^{19}$ In the context of indigenous peoples, the most vulnerable group in the indigenous community is fragile as their existence. Members of indigenous peoples and excluded social groups currently hold weak "civic" relationships with customary institutions. In occupying a lower quality of citizenship, they possess less ability for ownership of rights and materials. Therefore, it is important to strengthen civic engagement with these groups in order to achieve an inclusive society.

In democratic development, there are three traditions of participation: political, social, and citizen. ${ }^{20}$ Ross and Murray ${ }^{21}$ argue that the growing participation in society is influenced by many factors. Factors that influence a person to be willing to socially participate are namely: age, gender, education, occupation and income, and

17 Nawari Ismail, supra note 15 at 37.

18 Ruth lister, Inclusive Citizenship, Gender and Poverty: Some implications for education for citizenship, (Loughborough University, Citizenship Teaching and Learning Vol. 4, No. 1, July 2008) at 4 .

19 Clare Castillejo, Inclusive Citizenship Research Project: Methodology, Working Paper/Documente De Trabajo,(Spanyol: FRIDE, 2007). Archived on http://fride.org/descarga/FRIDE-WP73-INGLES.pdf.

20 Gaventa, J. and Valderrama, C,Participation, Citizenship and Local Governance - Background Paper for Workshop: Strengthening Participation in Local Governance', mimeo, IDS, Brighton, 21-24 June 1998, archived on www.ids.ac.uk/particip, https://www.uv.es/ fernandm/Gaventa,\%20Valderrama.pdf (5 March 2002) at 2.

21 Ross, Murray G., and B.W. Lappin, Community Organization: theory, principles and practice, second edition. (NewYork: Harper \& Row publishers, 1967) at 130. 
length of stay. ${ }^{22}$ Participation in a democratic political process involves the interaction of an individual or a political organization with a state expressed through organized action that includes voting, campaigning, and protest, with the aim of influencing the decisions of government representatives. Social participation in the development context is defined as community involvement, especially those seen as the heirs of development in consultation or decision-making at all stages of the development cycle. ${ }^{23}$ In this case, social participation is placed outside the formal institution of government. Citizen participation encompasses various forms of citizen participation in policy and decision making in key roles affecting their lives. ${ }^{24}$

Chambers divides participation into three forms: ${ }^{25}$ Cosmetic label, Co-opting Practice, and empowering process. Co-opting Practice used to mobilize personnel at the local level and reduce project finance. Empowering Process is interpreted as a process that enables local people to analyse their problems, think about how to overcome them, and gain the confidence to overcome these problems so as to make their own decisions alternative solutions. ${ }^{26}$

This study explores/documents/investigates/considers the participation and involvement of vulnerable groups in indigenous peoples in influencing policy (adat decisions) and customary agendas. Participation in this research is defined as the active involvement of local community members in decision-making about process of implementation and the programs that impact them. ${ }^{27}$

Participation is defined as an individual empowerment process for members of a particular group or community, in identifying and shaping the community model as they wish. Empowerment also intends for people to organize and influence change so that they gain stronger access to knowledge, may influence political processes, as well as manage social financing and existing natural resources. ${ }^{28}$ Participation of indigenous peoples can be gauged through their participation and involvement in customary agendas which include the formulation of customary policy and involvement in customary institutions.

\section{FORMS OF DISABILITY PARTICIPATION IN TORAJA AND BALI INDIGENOUS COMMUNITIES}

This paper will parse the participation of PwDs in indigenous peoples, as a group that is also vulnerable in indigenous groups. Participation is intended to encourage every citizen into exercising their rights to express their opinions in the decision-

22 Ibid.

23 Marshall Wolfe and Matthias Stiefel, A Voice for the Excluded: Popular Participation in Development: Utopia or Necessity., (London: Zed Books, 1994).

24 Gaventa and Valderrama, supra note 1 at 6.

25 Robert Chambers in Britha Mikkelsen. Methods for Development Work and Research: A New Guide for Practitioners. 2nd Ed. (California: Sage Publication, 2005), at 54.

26 Britha Mikkelsen. Methods for Development Work and Research: A New Guide for Practitioners. 2nd Ed. (California: Sage Publication, 2005), at 54.

27 Slocum et al,1995, dalam Adi Prasetio, Komuniti Lokal dan Akses Peran Serta Mereka Dalam Pengelolaan Sumber Daya Alam, (Jakarta: ICSD, 2003).

28 Ibid. 
making process about topics of public concern. In adat areas, persons with disabilities are often stigmatized as cursed and bearing sin, and therefore experience different treatment, especially concerning participation in traditional ceremonies. Thus, there exists multiple forms of vulnerabilities within indigenous communities. This can be most clearly observed in persons with disabilities within groups at the lowest social stratification.

\section{The Context of Disability and Indigenous Peoples in Bali}

Some indigenous communities have internal criteria for the categorization of persons with disabilities. In the village of Tenganan, Pagrisingan in Bali, people who are dimpil (blind) or have a cungih (cleft lip) are considered disabled and may not be a leader of the village krama desa. ${ }^{29}$ The presence of disabilities within indigenous communities often occurs due to marriage and conception of children between relatives. This is because some indigenous people allow marriage with close relatives. As with the modern day, Tenganan also does not know caste. In the past, people with disabilities were considered incompetent, so a model of incarceration existed. Now, people with disabilities can live freely like other Tenganan communities.

The Tenganan people are accustomed to providing explanations for persons with disabilities. Such deliberation is given, because disability is judged to be difficult while performing some religious rituals. The rituals in Bali Aga Tenganan are known to be very difficult to run even by non-disabled people. For that reason, people with disabilities may not do it. Bali Tenganan is an indigenous area of indigenous Bali that does not know caste, wherehe adat leaders are chosen by seniority in marriage. Although there is no caste, 3 Groups exist in Bali Tenganan: Krama Desa, Krama Gumi, and Krama Gumi Pulangan. Krama Desa is a structure whose members are elders and honors. Usually the members are a married couple who deserves to lead. Krama Desa is chosen based on the seniority of marriage. Those who lead are still husband or man. If one dies, then the partner must descend into Krama Gumi. Because the people of Tenganan know the marriage endogamy, if anyone married a non-Tenganan person, they may not be Krama Desa. Currently in Tenganan Pegringsingan there are 28 Heads of Family Krama desa and the leader is the senior, krama gumi 5, krama gumi pulangan 60 .

Persons with disabilities are raised by family, not adat, yet they enjoy free mobility in the village. ${ }^{30}$ In Krama Desa there is also a group, namely Luanan, or elderly people, in custom Tenganan pegringsingan. Then there are Kelian Desa, or adat leaders, and Pedenan, or people who prepare materials, who become Kelian or adat leaders. The Tenganan people are descendent from Hindu warriors from Indra God, known as war gods. Hence all the traditional ceremonies in this village are related to the war. Bali Tenganan traditional ceremonies are very heavy, so the indigenous people of Bali provide an exemption for people with disability.

29 Tody dan Aminatun, supra note, at 68.

30 Putu Yudiana, Perbekel / Kepala Desa Tenganan. Interview of Komnas HAM Research Team. September 14, 2017 at the office of Tenganan Village, Karangasem. 
For Bali Tenganan, persons with disabilities are freed in traditional ceremonies. In Tenganan, the Ayahan ritual is very heavy and takes 13 years. Persons with disabilities are given only 1 year for the implementation of Adat Ayahan. Severe rituals require strong physical and mental strength; therefore, persons with disabilities are free from the expectation to participate. For children younger than 12, there is a special ceremony which is conducted over 22 months. They are required to stay in dormitories and perform semedi rituals. Over the course of a year, they are trained to become ful Tenganan citizens. Inside the dormitory, they were taught karma and order in Tenganan custom. The ceremony is led by the leader of the senior family, and after the ceremony, it is said that the child is an adult.

Young people who have not performed this ceremony are not allowed to marry. If they do marry, they will be expelled for violating custom (as they are still considered children). Persons with disabilities that be freed from the ceremony are still allowed to marry. In the Tenganan indigenous community, there exists a customary law of endogamy marriage, where Tenganan may only marry Tenganan. Citizens who marry outside of Tenganan are no longer considered citizens of Tenganan. Regarding Tenganan Inheritance Rights, in contrast to Bali custom, Tenganan women have the same inheritance rights as Tenganan men. Though, if any citizen marries outside Tenganan, that person loses rights to inheritance. In this way, Persons with Disabilities have the same inheritance rights as other citizens.

The village of Bali Age recognizes stratification based on purity of marriage. They divided it into three: krama desa (village members), krama gumi (tenganan people married to outsiders still living in tenganan), krama bumi pulangan (married to outsiders, out of the village, and no longer social and spiritual social ties with his village). The right to use the natural resourcesin the village is the village Krama. Krama Desa members may only marry to fellow villagers so as to maintain purity of blood. If one does not follow this requirement, even if they are a person with a disability (eg torn deeds, they should not be a village krama), they may not become an elite.

During this time to sit in custom institutions or village apparatus is the head of the family who are classified in the Krama desa. Thus, PwDs are considered senior in Tenganan indigenous peoples, but may not be considered in the Krama Desa group. Disability cannot be Krama Desa. Even though it only tore his ear. men in this area have a habit of getting their ears pierced, but if they pierce their ears, they are deemed deformed, so they fall into a Krama Desa. Besides that, to become a Krama, Desa has to go through a very heavy ceremony. Historically the residents, of the Tenganan were knights who fought, so they were educated to go through a very heavy forging process. And the disability should not be in,this is because the order of the ceremony is very heavy, so for the disability given understandable, but also still eliminate the right and opportunity to be in the Krama Desa class.

Both indigenous peoples and those with disabilities are placed by the State in vulnerable groups whose social affairs still need to be improved in social welfare. In indigenous communities, disability is sometimes regarded as a "residual" or "a curse" so that the roles of indigenous peoples in community life are often not considered. 
The Kolok (mute and deaf) in the village of Bengkala are distinguished as people outside the Bengkala. Formerly, the kolok could not attend school and were not given a role in traditional ceremonies. Then on, a trusted figure is a Bengali resident who can communicate with the kolok and care about the kolok then encouraged them to live in one environment. "Kolok people" are then empowered economically for the assistance of one BUMN in Indonesia. Their activities especially that of dance and weaving, are widely exposed to gain the interest of the tourism industry.

In the Kubutambahan sub-district of Buleleng in Bali is the sub-village named Dinas or banjar dinas of the greater Bengkala village, in, where dozens of residents are either deaf or mute. These people are called Kolok and their population is composed of 45 person from 12 family heads. The village of Bengkala naturally communicates with the "kolok" residents. Kolok residents use their own mother tongue for everyday communication. The village government has cooperated with several related agencies on efforts to empower kolok residents. Resident kolok are taught to produce woven fabric, farm, and perform similarly economicallyindependent activities. In Bengkala village, a school has begun receiving kolok children to become more inclusive and to generally improve the knowledge base of the community.

Until recently, kolok people did not know read and write, given that they would use their mother tongue for communications Historically, they had no formal education system, so no one had ever occupied it as a village apparatus in banjar dinas. The interesting thing in kolok villages is the recognition of kolok language as the mother tongue which is then taught formally in school. The tradition of using the mother tongue is then transmitted to other communities through Ketut Kante. Mr. Ketut Kante is a teacher who succeeded in bringing this colloquial mother language into a formal language in school and is considered meritorious. ${ }^{31}$ Villages use a mix of kolok and common sign language. Kolok language is retained because it is the only sign language model in Indonesia and has been defined as local sign language in UNESCO for Indonesia. ${ }^{32}$

\section{The Context of Disability and Indigenous Peoples in Toraja}

Toraja people have different opinions regarding kolok people. The Torajan Society considers persons with disabilities as a blessing. At the same time, Toraja disabilities are also considered a curse, with a reason accompanying the manifestation of the disability in an individual. ${ }^{33}$ Given this, Toraja people are still figuring out the underlying reasons for disabilities. Usually these persons will ask God two main questions if they experience a sudden flaw ifit is through customary ritual process: (1) asking God the reason for being disabled; and (2) if the person believed they

31 Interview with Kepala Desa Bengkala I Made Arpama, Perbekel/Kades Bengkala, Rabu, 13 September 2017 in Desa Bengkala, Buleleng.

32 Interview with Ketut Kante, non-permanent teacher at SDN 2 Bengkala, SD inklusi. Ketut Kante is also known as a kolok language structure and is involved in the Kolok empowerment program in Bengkala Village.

33 Discussion at Kec. Senggala, Tana Toraja. 4 Oktober 2017. Kepala Kecamatan Sanggalla’ Mr. Bangna Padang. 
had made a mistake, they will perform a ritual apologizing to God and the spirit of the ancestors. The old principle of Toraja said, "if the leaves of wood become human and we are friends and family with them, especially if it is human". Given this proverb, the Toraja principally appreciate and love the PwDs among them.

People with disabilities receive specific facilities and assistance from the community in following customary ritual processes. For example persons with mental disabilities are often freed from customary obligations. In general, custom tailoring of conveniences is informed the advantages and disadvantages possessed. Given that the practice of customary rituals is fundamental to the Torajan community, even customary justice is a valid judicial practice as long as it does not concern one's life. Criminal matters involving life are resolved by legal mechanisms. The role of customary justice lies in the role of Tongkonan (Toraja traditional house) which is a symbol of the applicable scope of customary law. The role of persons with disabilities occupies the smallest possible role. The role is in accordance with the ability possessed. There is even a blind customary leader, whose position is given because of his wisdom and clear mind. One such role for the deaf and speech-impaired is to take care of the buffalo in the customary event such as funeral ceremony in Toraja (Rambusolok). The role is also adapted to caste / tana'.

The social order in Toraja has four levels, starting from below show class strata,: Tana 'kua-kua,type of wood that quickly decayed, but also eaten fruit; Tana 'karurung, Type of trong enau bark; Tana 'basi, The stronger, like the iron; Tana 'bulaan, Gold castle, glorious. Tana bulaan is the highest caste that is a royal or descendant of the king in toraja. They have Tongkonan, the Toraja traditional house. tongkongan means role, so in the tongkongan the role of all castes applies. Tongkonan is not merely a traditional house of Toraja but has legitimacy and function. Many new building like tongkonans are made by nomads, which establishes the tongkonan plot that has legitimacy and tongkonan as a mere home (Batu'ariri). Indeed every tongkonan must be custom house, but not all traditional houses can be called tongkonan. Tongkonan are called such because they have a function and role. Tongkonan is a traditional house building that is significant within this indigenous community because it is where meat distribution occurs. Batu'ari is only a family home and does not have any significant cultural function, position, or role.

Toraja custom rituals are inherently connected to two things: death, and the celebration of good things. Tongkonan as a community center for Toraja serves as a functional place for the role of religion, the role of justice, the role of security, and the role of welfare in the community. Tongkonan is the center of society where individuals may complain, seek justice, and discuss matters of concern. It is preserved in the Kombayan forum that people from different castes are free to argue. If it put to good use, the role of Tongkonan can be used to empower persons with disabilities. The idea can be developed in Tongkonan Guild (Buma \% Pengaringan). The coordinative nature of the alliance has the ability to cover the scope of 3 subdistricts consisting of 24 custom territories. The role of 
empowerment can fill and complement the role of local government in establishing an inclusive society.

\section{Encourage Inclusive Disability Participation in Indigenous Peoples}

It is undeniable that indigenous peoples themselves experience from the State, especially if they also are persons with disabilities. The vulnerability of the individual is exacerbated if they are both disabled and indigenous. Customary institutions are a potential bridge for this problem. In the tradition of sociology, Adat Pranata is a compilation of related knowledge about the bad, the wrong, and the truths about life (social values) that are codified into the rules of behaviour for all members. This compilation is guarded by those in roles of leadership (social position) who are critical for its implementation. Customary institutions into encompass three social dimensions: the long-established social values, the role of leadership in maintaining a set of rules, and practices of social value that has been used as the daily habits of its members. ${ }^{34}$ From the description, it is clear that customary institutions serve to maintain social order with a model of leadership in indigenous peoples. This means that the harmonization of indigenous peoples' lives must continue to be tied with the existence of customary institutions.

Customary Institutions are unwritten rules. Although no documents have been written, indigenous peoples are able to carry out such customary institutions as part of their daily life. Without written rules, indigenous peoples have been able to build and maintain community values for their lives. This power can be used to promote the potential for protection and the fulfilment of rights for vulnerable groups in indigenous peoples.

Adat leaders and customary institutions have been able to perform their functions and influence the operation of customary institutions. One example of which is to encourage specific institutions to take root in the culture and society without any conflict of interest. Usually all problems will be solved in the Tongkongan Buka which is a place for discussion and deliberation. Customary stakeholders will determine whether or not that adat can be implemented, according to whether or not adat is implemented and share the role in the traditional ceremony. The rules followed by Toraja peoples are held to a high value and integrated into their lives as a guide. In Chambers theory, inclusive participation can also be referred to as the empowering process. ${ }^{35}$ Person with disabilities are included in traditional ceremonies and also get the distribution of sacrificed buffalo meat. Sometimes they get more results. The role of persons with disabilities is adjusted to their needs, sometimes they may also collect caterpillars and cleanse them from the dead king's body. In its history there has been a traditional leader who has a blind disability in Luwuk Toraja. And its leadership is also recognized by its citizens. Toraja who have held strong traditions for a long

34 Novry Susan, Peran Pranata Adat Dalam Pencegahan/Penghentian Konflik Antara Kelompok Masyarakat, Research Report Pusat Penelitian dan Pengembangan Sistem Hukum Nasional, (Jakarta:BPHN RI, 2014). Archived on https:/www.bphn.go.id/data/documents/laporan_ akhir_final_pranata_adat_2014_lengkaatpdf.

35 Robert Chambers in Britha Mikkelsen, loc c cit. at 54. 
time, but recognize the existence of disability and give their role in adat. This is called inclusive participation in chambers. In contrast to Toraja, in chambers theory currently, tangible participation in cosmetic labels and coopting practice can be encountered in kolok. Forms of participation include the involvement of community groups in economic empowerment programs and the release of requirements in traditional ceremonies in the Balinese Tenganan community. The role of the kolok is not directly driven by adat, but by people who are able to represent the kolok and its empowerment is carried out by the private sector. These are harmonized so as to not disturb established customary institutions with disability involvement. While forms of Coopting Practice can also be encountered in Toraja custom ceremony such as the funeral ceremony or other ceremonies involving tongkonan persons with disabilities can still participate in any of these ceremonies, though that participation is limited to certain levels.

Inclusiveness is a matter of engagement. Inclusiveness also relates to the importance of solidarity. In encouraging inclusive participation in indigenous peoples, it also requires the recognition of disability, as well as that of indigenous peoples as citizens. The establishment and maintenance of inclusionary citizenship requires the state to provide protections for, and fulfilment the rights of, all citizens. It is also the responsibility of the state to provide protections while recognizing the internal diversity and vulnerabilities within indigenous and tribal communities. Increased accessibility for persons with disabilities in indigenous peoples, especially of education, health and public services, are urgently needed.

Achieving inclusive participation in indigenous communities requires the full involvement and responsibility of all parties. Vulnerable groups have the same rights to protection and fulfilment of rights in accordance with the law as other citizens. Referring to the efforts to enact a Law on Indigenous Peoples and including vulnerable groups in indigenous peoples, it should be noted that indigenous peoples can practice harmony within their own groups. it means that what must be regulated is the issue of their recognition as part of citizens and the protection and fulfilment of their rights. While the rules regarding how the lives of indigenous peoples in each group have been set in their own soft law. Although people with disabilities are considered as cursed by ancestors, they are still part of the living values that have existed in the culture since those ancestors. It is important to note that the state respects their beliefs so as to preserve ancestral values. Like other citizens, the state also has a responsibility to environmental guardian (memenjan) in indigenous communities, a phenomenon known as collective rights, which refer to the basis of the rights of the ecosystem.

Disability issues are individual rights that cannot be regulated in customary law, even though customary law already has a clear, though not written, arrangement. ${ }^{36}$ Indigenous peoples are known to have strong kinship but weak social solidarity. It is difficult to find social mobility when faced with social problems. ${ }^{37}$ But this unwritten customary rule is a value system that unites it, Indigenous peoples are not aware of

36 Interview with Prof. Dr. Purwo Santoso, on Thursday, 24 Agustus 2017, pukul 17.30 s.d 19.15 WIB at FISIPOL UGM.

37 Ibid. 
their vulnerability that habits have excluded them. That there are indeed differences, but only regulate the course of customary rules that have gone harmoniously. For that national law that is able to accommodate a plurality of laws is more needed.

\section{CONCLUSION}

Disability participation in indigenous peoples is present in various forms according to the conditions and values of Adat each that has lived and developed so far. In Toraja the meaning of disability from stigma into humanist approach begins to be seen in interpreting the disability of the titles of "Karma", "residual", "Curse" or sin, shifting to the assumption that their birth as a blessing and begin to give roles in indigenous peoples.

For hundreds of years, the prevailing customary institutions have heavily informed the social life of indigenous peoples. What is needed by indigenous peoples is a more moderate collective right which are written specifically to tailor to the needs of vulnerable groups. The space for participation in public spaces is a necessity. This means that the inclusive participation of these vulnerable groups should be assessed on a par with other groups within indigenous peoples. Because customary rules have already defined that the participation of indigenous disabled persons is limited, it may fall to the Adat to empower and promote mutual care within indigenous peoples. To realize inclusive citizenship, governments should provide equal access and public services to all levels of society within indigenous communities.

\section{BIBLIOGRAPHY}

Arizona, Yance et al., Pengakuan Hukum terhadap Masyarakat Adat: Tren Produk Hukum Daerah dan Nasional Pasca Putusan MK 35/PUU-X/2012, 2017, (Jakarta: Epistema Institute, 2017).

Castillejo, Clare, Inclusive Citizenship Research Project, Working Paper/Documente De Trabajo, (Spanyol: FRIDE, 2007).

Cunningham, Mirna and Sena, Paul Kanyinke, "Study On The Situation Of Indigenous Persons With Disabilities, With A Particular Focus On Challenges Faced With Regard To The Full Enjoyment Of Human Rights And Inclusion In Development",, ESC. Twelf Session, item 7 of Provisonal Agenda. E/C.19(2013).

Factsheet United Nation Permanenet Forum on Indegenous Issues, "Who are indigenous peoples?". www.un.org/esa/socdev/unpfii/documents/5session_factsheet1.pdf

Gaventa, J. and Valderrama, C, Participation, Citizenship and Local Governance Background Paper for Workshop: Strengthening Participation in Local Governance', mimeo, IDS, Brighton, 21 -24 June 1998, www.ids.ac.uk/particip (5 March 2002). 
Interview of Komnas HAM team with Ketut Kante, honorary teacher at SDN 2 Bengkala, SD inclusion. Ketut Kante is also known as a kolok language structure and is involved in the Kolok empowerment program in Bengkala Village.

Interview of Komnas HAM team with Village Head of Bengkala I Made Arpama, Perbekel / Kades Bengkala, Wednesday, 13 September 2017 at Bengkala Village office, Buleleng.

Interview of Research Team Komnas HAM by Tilang Pandilerung alias Pong Barumbun, at TOngkonan Buka, Desa Misa, Buntao District, Tana Toraja. Tuesday October 3, 2017.

Interview of Research Team Komnas HAM with Kolok Village Head, Wednesday, September 13, 2017

Interview of Research Team Komnas HAM with Prof. Purwo Santoso, Lecturer of Faculty of Social and Political Sciences UGM, Thursday, August 24, 2017, at 17.30 s.d 19.15 WIB at UGM FISIPOL

Interview of Research Team Komnas HAM with Sanggalla District Head, Tana Toraja, Bp. Bangna Padang, October 4, 2017.

Interview of Research Team with Komnas HAM Village Head / Perbekel Tenganan, Bali, Bp. I Putu Yudiana, September 14, 2017 at Tenganan Village office, Karangasem

Ismail, Nawari, Perubahan Sosial Budaya Agama Dam, (Deepublish: 2016).

John Griffith, “What is Legal Pluralism' Journal of Legal Pluralis, 1986, nr-44.

Mikkelsen, Britha, Methods for Development Work and Research: A New Guide for Practitioners. $2^{\text {nd }}$ Ed. (California: Sage Publication, 2005).

Mikkelsen, Britha. Methods for Development Work and Research: A New Guide for Practitioners. $2^{\text {nd }}$ Ed. (California: Sage Publication, 2005).

Novry Susan, Peran Pranata Adat Dalam Pencegahan/Penghentian Konflik Antara Kelompok Masyarakat Laporan Penelitian Pusat Penelitian dan Pengembangan Sistem Hukum Nasional, (Jakarta:BPHN RI, 2014). Archived on

https://www.bphn.go.id/data/documents/laporan_akhir_final_pranata_adat_201 4_lengkap.pdf

Patittinggi, Faridda, "Peranan Hukum Adat Dalam Pembinaan Hukum Nasional Dalam Era Globalisasi”, Majalah Ilmu Hukum Amanna Gappa, Vol.11 No. 13, Januari-Maret 2003, Fakultas Hukum Universitas Hasanudin Makassar.

Prasetio, Adi, Komuniti Lokal dan Akses Peran Serta Mereka Dalam Pengelolaan Sumber Daya Alam, (Jakarta: ICSD, 2003).

Propiona, Jane Kartika et al, Buku Implementasi Hak Asasi Manusia di Indonesia: Hak Kesehatan dan Jaminan Sosial Bagi Penyandang Disabilitas di Kabupaten 
Daerah Tertinggal, (Pusat Penelitian Kemasyarakatan dan Kebudayaan: LIPI, 2013).

Ross, Murray G., and B.W. Lappin. (1967). Community Organization: theory, principles and practice. Second Edition. NewYork: Harper \& Row Publishers.

Sasmitha, Tody dan Zubaedah, Aminatun, Difabel (Perempuan) dalam Masyarakat Adat, (Yogyakarta: Sentra Advokasi Perempuan, Difabel dan Anak /SAPDA, 2017).

Sepuldeva, M., Van Banning, T., \& van Genugten, W. J. M. Human Rights Reference Handbook. (Costa Rica: University for Peace, 2004).

The State of The World's Indigenous People Press Release, United Nations Department of Public,14 January 2010, Information-DPI/2551/K-09-64058 January 2010

The State of The World's Indigenous People, ST/ESA/328, 2009

Twikromo, Y.Argo, The Local Elite and the Appropriation of Modernity: A Case In East Sumba, Indonesia, (Yogyakarta: Kanisius, 2008).

Wolfe, Marshall and Stiefel, Matthias, A Voice for the Excluded: Popular Participation in Development: Utopia or Necessity?; (London: Zed Books, 1994).

Isnenningtyas Yulianti is Researcher at Komnas HAM. She holds a MA in Human Rights and Democration at the Faculty of Politics and Government Studies, Gadjah Mada University. Isnenningtyas Yulianti, had been working in the field of ESC rights. Her researches mostly on the rights of minorities, especially persons with disabilities, womens right and indigenous peoples, and the Right to Food. On the issue of disability, she has completed various studies such as the drafting of Persons with Disabilities Bill, and the preparation of a CRPD initiative report by Komnas HAM. For other ESC rights issues, she and the National Commission on Human Rights have completed the preparation of indicators on the right to food, the right of housing, the right to health and employment. The issue of indigenous peoples was started by her in the study of the preparation of the input of the Draft Bill on Indigenous Peoples. To contact Yulianti, please email tyas.yulianti@gmail.com

Nurrahman Aji Utomo is a researcher at Komnas HAM. He holds a Bachelor of Laws from Sebelas Maret University and a Master of Laws from Gadjah Mada University. Nurrahman Aji Utomo explored issues of constitutional law and its slice with human rights. In some of his studies, he explored the legislation process, institutions on the issue of gross human rights violations in Indonesia. To contact Aji Utomo, please email nurrahmanajiutomo@gmail.com 